\title{
MODEL MANAJEMEN PEMBERDAYAAN MASYARAKAT MELALUI PENGOLAHAN SAMPAH ORGANIK RUMAH TANGGA UNTUK MENINGKATKAN NILAI TAMBAH EKONOMIS SERTA MENJAGA KELESTARIAN LINGKUNGAN HIDUP
}

\author{
Agus Hasbi Noor ${ }^{1}$, Tita Rosita ${ }^{2}$ \\ 1,2 IKIP Siliwangi - Cimahi - Jawa Barat - Indonesia \\ 1agushasbinoor@gmail.com
}

\begin{abstract}
Received: April, 2020; Accepted: Mei, 2020

This study describes a model of community empowerment that has been successfully developed through the management of household organic waste in urban areas by involving a number of housewives who are members of the Sauyunan Women's Farmer Group (KWT) in RW 03 Sarijadi Urban Bandung, the research method uses descriptive qualitative methods which is processed from the results of observations, interviews and documentation studies. Findings in the field show that the success of KWT Sauyunan in mobilizing the potential in its environment is one of the empowerment models that can be tested elsewhere.
\end{abstract}

Keywords: Community Empowerment Management, Organic waste, Economic added value

\begin{abstract}
Abstrak
Penelitian ini mendeskripsikan sebuah model pemberdayaan masyarakat yang telah berhasil dikembangkan melalui pengelolaan sampah organik rumah tangga di daerah perkotaan dengan melibatkan sejumlah ibu rumah tangga yang tergabung dalam Kelompok Wanita Tani (KWT) Sauyunan di RW 03 Kelurahan Sarijadi Kota Bandung, metode penelitian menggunakan metode deskriptif kualitatif yang diolah dari hasil observasi, wawancara dan kajian dokumentasi. Temuan di lapangan menunjukkan bahwa keberhasilan KWT Sauyunan dalam menggerakkan potensi di lingkungannya merupakan salah satu model pemberdayan yang dapat diuji cobakan di tempat lai

Kata kunci : Manajemen Pemberdayaan Masyarakat, Sampah organik, Nilai tambah ekonomis

How to Cite: Noor, A.H \& Rosita, T. (2020). Model Manajemen Pemberdayaan Masyarakat Melalui Pengolahan Sampah Organik Rumah Tangga Untuk Meningkatkan Nilai Tambah Ekonomis Serta Menjaga Kelestarian Lingkungan Hidup. Comm-Edu (Community Education Journal) 3 (2), 167-173.
\end{abstract}

\section{PENDAHULUAN}

Pembangunan akan berhasil jika didukung oleh manusia yang terampil, cakap, dan bertanggung jawab serta dapat mengabdi kepada nusa dan bangsa. Dengan semakin bertambahnya penduduk usia produktif perlu dikembangkan potensi semaksimal mungkin, sesuai dengan tuntutan Negara yang tercantum dalam GBHN 1988, yaitu : " jumlah penduduk yang sangat besar apabila di bina dan dikerahkan sebagai tenaga kerja yang efektif akan merupakan modal pembangunan di segala bidang".

Pembangunan nasional dimaksudkan untuk membangun manusia Indonesia, sehingga pembangunan sebagai usaha peningkatan kualitas manusia dan masyarakat Indonesia yang dilaksanakan secara berkelanjutan, berlandaskan kemampuan nasional dengan memanfaatkan kemajuan ilmu pengetahuan teknologi serta memperhatikan tantangan perkembangan global. 
168 Noor \& Rosita, Model Manajemen Pemberdayaan Masyarakat Melalui Pengolahan Sampah Organik Rumah Tangga Untuk Meningkatkan Nilai Tambah Ekonomis Serta Menjaga Kelestarian Lingkungan Hidup

Dalam pelaksanaannya mengacu kepada kepribadian bangsa dan nilai luhur yang universal untuk mewujudkan kehidupan bangsa yang berdaulat, mandiri, berkeadilan, sejahtera, maju dan kukuh kekuatan moral etikanya.

Tertarik dengan permasalahan di atas, terutama yang berkaitan dengan bagaimana upaya tokoh masyarakat dalam memotivasi para warga masyarakat khususnya ibu-ibu dalam mengolah sampah organik dan sampah rumah tangga untuk dijadikan menjadi pupuk cair untuk penyubur tanaman yang disebut Mikro Organik Lokal (MOL). Ibu-ibu yang bertempat tinggal di RW 03 kelurahan Sarijadi Kecamatan Sukasari Kota Bandung dilibatkan dalam pengolahan sampah organik tersebut tergabung dalam Kelompok Wanita Tani Sauyunan Untuk itu penulis bermaksud mendalaminya malalui sebuah penelitian ilmiah yang dirumuskan ke dalam sebuah judul : "Model Manajemen Pemberdayaan Masyarakat Melalui Pengolahan Sampah Organik Rumah Tangga Untuk Maningkatkan Nilai Tambah Ekonomis Serta Menjaga Kelestarian Lingkungan Hidup"

Berangkat dari permasalahan di atas, perlu adanya upaya dan kepedulian dari berbagai pihak baik pemerintah maupun warga masyarakat untuk melakukan berbagai cara dalam pengelolaan lahan kritis dan lahan sempit melaui kegiatan urban farming. Para tokoh masyarakat baik Ketua RW maupun aparat Kelurahan berusaha membuat terobosan yaitu dengan cara mengajak warga masyarakat untuk mengolah sampah organik dan sampah rumah tanngga dalam rangka meningkatkan kesejahteraan dan kepedulian warga masyarakat terhadap keberadaan lingkungan.

\section{KAJIAN TEORI}

\section{Konsep Pemberdayaan}

Pemberdayaan merupakan terjemahan dari empowerment, yang berasal dari kata "power" yaitu kekuatan. Istilah pemberdayaan dapat dikaitkan dengan proses transformasi sosial, ekonomi dan politik (kekuasaan). Konsep pemberdayaan pada dasarnya adalah upaya menjadikan suasana kemanusiaan yang adil dan beradab menjadi semakin efektif secara struktural, baik di dalam kehidupan keluarga, masyarakat, negara, regional, internasional dalam bidang politik, ekonomi dan lain lain.

Suzanne Kindevatter dalam bukunya Nonformal Education as an Empowering Process (1979) dalam Djudju Sudjana (2000 : 77), mengemukakan konsep pemberdayaan atau Empowering Process. Konsep ini bermakna bahwa "People gaining an understanding of and control over social, economic, and lor political forces in order to improve their standing in societv". Proses pemberian kekuatan atau pemberdayaan adalah setiap upaya pendidikan yang bertujuan membangkitkan kesadaran, pengertian, dan kepekaan peserta didik terhadap perkembangan sosial, ekonomi dan atau politik, sehingga pada gilirannya peserta didik memiliki kemampuan untuk memperbaiki dan meningkatkan status sosial, ekonomi dan politiknya dalam masyarakat. Pemberdayaan adalah proses membantu individu atau masyarakat dalam menciptakan pemahaman baru sekaligus memberi kebebasan untuk membuat pilihan. Dengan kata lain pemberdayaan adalah proses meningkatkan kekuatankekuatan dari dalam diri individu, seperti kompetensi dan kreativitasnya serta meningkatkan kebebasan orang tersebut dalam bertindak.

Kesimpulan di atas mengungkapkan bahwa pendidikan, khususnya pendidikan luar sekolah, sebagai proses pemberdayaan adalah suatu pendekatan pendidikan yang bertujuan untuk meningkatkan pengertian dan pengendalian diri peserta didik terhadap kehidupan sosial, 
ekonomi dan/atau politik sehingga peserta didik mampu untuk meningkatkan taraf hidupnya dalam masyarakat. Untuk itu proses yang perlu ditempuh peserta didik adalah : (1) melatih tingkat kepekaan yang tinggi terhadap berbagai aspek perkembangan sosial, ekonomi dan politik selama proses pembelajaran, (2) mempelajari berbagai macam keterampilan untuk memenuhi kebutuhan dan untuk memecahkan masalah yang dihadapi, dan (3) bekerja sama dalam memecahkan masalah yang dihadapi bersama.

Pelatihan adalah upaya untuk mengembangkan sumber daya manusia, terutama untuk mengembangkan kemampuan intelektual, keterampilan dan kepribadian manusia. Pelatihan (training) sering dikacaukan penggunaannya dengan latihan (practice atau exercise) ialah merupakan bagian dari suatu proses pendidikan, yang tujuannya untuk meningkatkan kemampuan atau keterampilan khusus seseorang atau kelompok orang. Dengan demikian dapat dikatakan bahwa pelatihan merupakan proses pembelajaran untuk meningkatkan kinerja orangorang dalam menyelesaikan pekerjaan. Pelatihan adalah suatu proses yang menciptakan kondisi dan stimulus untuk menimbulkan respons terhadap orang lain, mengembangkan pengetahuan dan keterampilan (skill) dan sikap, menciptakan perubahan tingkah laku, dan untuk mencapai tujuan yang spesifik.

\section{Pengertian Manajemen}

Kata manajemen berarti, pemimpin, direksi dan pengurus, yang diambil dari kata kerja "manage" berarti mengemudikan, mengurus, dan memerintah. Istilah management berasal dari bahasa Italia "managere" berarti melatih kuda, sebagai pelatih. Menurut istilah latin managmement, manageire mempunyai arti melakukan, melaksanakan, mengurus sesuatu, sebab kata managere terdiri dari dua kata, manus dan agree, manus berarti tangan dan agaree berarti melakukan atau melaksanakan (Gunur, 1976:6).

Menurut Terry dalam Daeng (2014:34) mengatakan bahwa manajemen adalah: "A distinct process consisting of planning, organizing, actuating and controlling, performed to determine and accomplish state objective by the use of human beings and order resources.(Proses yang berbeda yang terdiri dari perencanaan, pengorganisasian, pelaksanaan dan pengendalian, dilakukan untuk menentukan dan mencapai tujuan negara dengan menggunakan manusia dan sumber daya).

Sejalan dengan sejarah perkembangan dan berdasarkan situasi penerapannya, manajemen meliputi berbagai fungsi. Fungsi manajemn menurut Morris (1976) dalam Djuju Sudjana (2010:47) adalah rangkaian berbagai kegiatan wajar yang telah ditetapkan dan memiliki hubunngan saling ketergantungan antara yang satu dengan yang lainnya, dan dilaksanakan oleh orang-orang, lembaga atau bagian-bagiannya, yang diberi tugas untuk melaksanakan kegiatankegiatan tersebut.

Djuju Sudjana (2010:51) mengemukakan manajemen pendidikan non formal terdiri atas enam fungsi yang berurutan, fungsi tersebut adalah : perencanaan, pengorganisasian, penggerakan, pembinaan, penilaian dan pengembangan.

\section{Konsep Keterampilan}

Istilah keterampilan sulit untuk didefinisikan untuk suatu kepastian yang tidak dapat dibantah. Keterampilan dapat menunjuk pada aksi khusus yang ditampilkan atau pada sifat dimana keterampilan itu dilaksanakan. Banyak kegiatan dianggap sebagai suatu keterampilan, atau 
170 Noor \& Rosita, Model Manajemen Pemberdayaan Masyarakat Melalui Pengolahan Sampah Organik Rumah Tangga Untuk Meningkatkan Nilai Tambah Ekonomis Serta Menjaga Kelestarian Lingkungan Hidup

tediri dari beberapa keterampilan dan derajat penguaasan yang dicapai oleh seseorang menggambarkan tingkat keterampilannya.

Keterampilan ini dapat didefinisikan dengan dua cara. Pertama, dengan mengangapnya sebagai kata benda, yang menunjuk pada suatu kegiatan tertentu yang berhubungan dngan seperangkat gerak yang harus dipenuhi syarat-syaratnya agar bisa disebut suatu keterampilan. Kedua, dengan menganggapnya sebagai kata sifat. Yang sudah dilakukan orang selama ini dalam kaitannya dengan istilah keterampilan baru terbatas pada penjabaran definisi dalam konteks yang terakhir.

Menurut Schmidt (1991) dalam Agus Mahendra dan Amung Ma'mun (1998:131) bahwa : "keterampilan merupakan kemampuan untuk membuat hasil akhir dengan kepastian yang maksimum dan pengeluaran energi dan waktu yang minimum". Sedangkan menurut Singer (1980) dalam Agus Mahendra dan Amung Ma'mun (2008:142) bahwa keterampilan adalah derajat keberhasilan yang konsisten dalam mencapai suatu tujuan dengan efisien dan efektif.

Dalam hal ini keterampilan yang digunakan adalah keterampilan fungsional. Pendidikan keterampilan fungsional sebagai sub sistem pendidikan mengandung maksud, kajian pendidikan keterampilan fungsional merupakan salah satu fenomena pendidikan yang senantiasa menjadi pembahasan dari para ahli pendidikan. Ada 3 landasan dikembangkannya model pendidikan keterampilan fungsional, yaitu :

Secara teoritis; yang melandasi dikembangkannya model pendidikan keterampilan

Fungsional, diantaranya pemikiran perenialisme dalam kaitannya dengan pembentukan pribadi dan sifat-sifat mental, esensialisme yang bersifat pragmatis dengan orientasi pengembangan pada pembentukan keterampilan dan pengembangan kemampuan vocational (Diana Lapp, 1975:32). Teori pendidikan pribadi terutama aliran progressive yang menekankan prinsip belajar sambil bekerja (learning by doing).

Secara operasional; ditegaskan bahwa pendidikan keterampilan fungsional merupakan keterampilan yang memiliki potensi untuk dijadikan bekal oleh warga belajar dalam berkarya, berusaha, dan dapat memberikan penghasilan untuk menjalani kehidupan sehari-hari. Pendidikan keterampilan fungsional dapat dilakukan melalui pelaksanaan program-program dengan mengadakan penyesuaian terhadap (1) Kurikulum yang berorientasi terhadap lingkungan, lentur terhadap perubahan dunia kerja dan masyarakat (2) Isi dan struktur program pendidikan keterampilan fungsional (pendidikan untuk semua sesuai dengan kebutuhan masyarakat dan dunia kerja).

Secara empiris; salah satu misinya mengembangkan budaya prestasi dan sikap produktif. Di lain pihak secara aplikatif, penyelenggaraan pendidikan keterampilan fungsional sebagai bagian dari sistem pendidikan terpadu, namun masih lemah dalam manajemen, proses belajar mengajar dan evaluasi hasil, seperti halnya yang telah berjalan di beberapa pondok pesantren dan lembaga social ekonomi masyarakat.

\section{PEMBAHASAN}

Pembekalan keterampilan bagi warga untuk mengolah sampah baik organik maupun anorganik menjadi barang-barang yang lebih bermamfaat dan memiliki nilai ekonomis cukup tinggi merupakan salah satu penerapan pemilihan dalam usaha untuk membatasi volume sampah yang merupakan bagian terpenting dalam pengelolaan sampah disuatu masyarakat dengan pola intensif.di katakan kegitan pengelolaan sampah yang di lakukan dikoordinasi secara langsung 
oleh Ibu-ibu rumah tangga bekerjasama dengan pengelola bank sampah. Dengan memberikan pembekalan pada warga berupa keterampilan cara mengelola sampah, akan ditemukan satu langkah yang inovatif dalam usaha yang membiasakan masyarakat memilah-milah sampah, dan pada akhirnya masyarakat akan lebih menghargai sampah sesuai dengan nilai dan jenisnya sehingga mau untuk memilah sampah yang pada saat nya dapat mengurangi timbunan atau volume sampah.keterampilan mengolah sampah juga dapat menumbuh kembang kan perekonomian rakyat karena warga dapat berperan aktif memamfaatkan sampah rumah tangga yang berupa kulit worten, kulit kentang, kulit buah-buahan dan kulit sayuran lainnya untuk diolah menjadi pupuk cairan yang disebut dengan Mikro Organik Lokal (MOL).

Mikro organik Lokal ini merupakan pupuk tanaman yang berbentuk cairan yang terbuat dari sampah rumah tangga atau sampah dapur yang khasiatnya melebihi pupuk lain yang terbuat dari zat kimia, MOL ini pembuatannya sangat sederhana sekali dan bisa dilakukan oleh siapapun dan yang dapat menambah penghasilan

Ibu-ibu rumah tangga di Kelurahan Sarijadi memiliki beberapa pola pengelolaan. sampah dengan cara di buang, di bakar serta di timbun. pada masyarakat yang pola pengelolaan sampah dengan cara dibuang dilakukan dengan cara membuang sampah di sungai dan lumbang.sedangkan pada masyarakat yang memusnahkan sampah dengan cara membakar dan atau menimbun tanpa memilah terlebih dahulu akan memberikan dampak pencemaran lingkungan jangka panjang.Di tambah dengan kebiasaan primitif dimana masih banyak yang sekedar membuang bungkusan sampah dengan sengaja di sepanjang jalan.

Keberhasilan dalam penanganan masalah sampah harus di dukung oleh tingkat kesadaran Ibuibu rumah tangga yang sangat tinggi, sosialisasi dan penyuluhan mengenai pengelolaan sampah menjadi sesuatu yang memiliki nilai jual sudah pernah di adakan sebelumnya tetapi mengalami kemacetan dan tidak berlanjut karena kesadaran masyarakat hanya ada pada saat program di jalankan, dari sini dapat diketahui bahwa sumber masalah dari pengelolaan sampah yang kurang tepat berawal dari pola perilaku masyarakat yang bersangkuatan.

Pola perilaku yang baik merupakan salah satu tolok ukur pola pemikiran yang baik pula.Secara sosiologis,pola perilaku masyarakat merupakan pengejawentahan dari pribadi yang bersangkutan untuk nantinya berubah menjadi tindakan sosial.

Pengolahan sampah organik yang dilaksanaakan di RW 03 kelurahan Sarijadi, memamfaatkan sampah organik dan sampah yang berasal dari rumah tangga yang dilakukan oleh sebagian besar ibu-ibu rumah tangga yang tergabung dalam kelompok wanita tani sauyunan yang ada di RW 03. Dengan didorong oleh keinginan yang kuat dan atas prakarsa salah seorang ibu rumah tangga yang kebetulan alumni STKIP Siliwangi angkatan 2002, beliau memiliki kepedulian terhadap keberadaan lingkungan yang selama ini banyak sampah berserakan, kotor dan tidak terurus.

RW 03 terdiri dari 10 RT, sedangkan yang aktif mengikuti kegiatan pengolahan sampah organik sebanyak 25 orang. Dari ke 25 orang tersebut hampir 90 persen murni sebagai ibu rumah tangga. Dan 10 persen bekerja sebagai karyawan swasta dan PNS. Ibu-ibu yang aktif dalam mengolah sampah organik, otomatis menjadi anggota kelompok wanita tani kebun sauyunan. Yang biasanya mereka setelah pulang mengikuti kegiatan senam, saat ini mereka memiliki kegiatan lain yaitu mengolah sampah organik dengan penuh semangat. Ternyata dari usaha pengolahan sampah tersebut sudah dapat dinikmati hasilnya, yaitu berupa pupuk cair dan pupuk kering. Selain berupa finansial yang diperoleh para ibu-ibu, keuntungan lain adalah berbagai keterampilan dalam mengelola sampah organik yang berasal dari kulit sayuran 
172 Noor \& Rosita, Model Manajemen Pemberdayaan Masyarakat Melalui Pengolahan Sampah Organik Rumah Tangga Untuk Meningkatkan Nilai Tambah Ekonomis Serta Menjaga Kelestarian Lingkungan Hidup

seperti; wortel, kentang, bawang, cabe, ketimun dll. Para ibu-ibu dilatih pula cara membuat pupuk cair yang disebut MOL (Micro Organik Lokal) merupakan pupuk cair yang berasal dari sampah organik yang dipermentasi dan merupakan pupuk unggulan sebagai penyubur tanaman.

Mekanisme kemitraan yang dilakukan dengan pihak sekolah yang ada di sekitar RW 03, serta Dinas pertanian Kota Bandung.

\section{Green School}

Green School adalah program berkebun berbasis sekolah yang dekat dengan lingkungan RW 03, tujuan dari program ini adalah edukasi dan pengolahan sampah organik berbasis sekolah dimana halaman-halaman di sekolah yang tadinya gersang banyak sampah dan rumput kering dirubah menjadi green school. Sedangkan sampah yang berserakan berupa sampah organik yang biasanya dibakar dan ditimbun dijadikan kompos untuk kebutuhan kompos dan dapat dimanfaatkan untuk penyubur tanaman bunga atau sayuran di sekolah sementara sampah anorganiknya dijadikan tabungan karena di setiap sekolah yang mendapat program ini dibentuk Bank Sampah Sekolah. Adapun sekolah yang dibina dalam program ini sebanyak 3 sekolah diantaraanya :

Tabel 1. Sekolah Binaan Pengolahan Sampah Organik

\begin{tabular}{|l|l|l|}
\hline No & Nama Sekolah & Alamat \\
\hline 1 & SDN Sarijadi 5 & RT 02 RW 03 \\
\hline 2 & SMP PGRI 5 & RT 01 RW 03 \\
\hline 3 & MI Nurulhuda & RT 01 RW 03 \\
\hline
\end{tabular}

\section{KESIMPULAN}

Melalui pelatihan keterampilan bagi para ibu-ibu KWT Sauyunan yang ada di Kelurahan Sarijadi , disambut baik oleh para anggota KWT Sauyunan, karena melalui pelatihaan ini ibuibu dituntut untuk mampu mengembangkan keterampilan dan kemampuannya serta sekaligus dapat merubah pola pikir para tentang pentingnya pengetahuan penggunaan keterampilan khususnya dalam pengolahan sampah organik untuk dijadikan pupuk kering dan pupuk cair yang disebut MOL.

Pelatihan keterampilan pengelolaan sampah bagi para ibu-ibu dan masyarakat merupakan salah satu upaya untuk memperoleh penghasilan serta penyadaran jangka panjang terkait pentingnya pengelolaan sampah guna peningkatan keterampilan bagi para ibu-ibu KWT Sauyunan yang ada di RW 03 Kelurahan Sarijadi,dan dapat mengimplementasikannya di masyarakat khususnya untuk peningkatan ekonomi.

Ibu-ibu KWT Sauyunan mampu mengelola sampah yang dimulai dari langkah awal pada kesadaran mengumpulkan, pemilahan sampah untuk nantinya memanfaatkan sampah organik untuk dijadikan pupuk sesuai dengan jenis sampah agar lebih bermanfaat. ibu-ibu KWT Sauyunan dapat memahami pentingnya mengolah sampah organik dan sampah rumah tangga sebagai alternatif untuk berwirausaha dengan memberi nilai ekonomis yang tinggi, serta untuk melestarikan lingkungan.

Melalui pelatihan keterampilan pengelolaan sampah, masyarakat sadar dengan adanya pengolahan sampah menjadi pupuk yang memiliki daya jual yang tinggi juga lingkungan 
menjadi bersih, indah, sehat, dan sampah bukan lagi sebagai masalah tetapi dapat bermanfaat bagi kehidupan manusia.

\section{DAFTAR PUSTAKA}

Coomb, H \& Manzoor, A. (2003). Memerangi Kemiskinan di Pedesaan Melalui Pendidikan Non Formal. Bank dunia.

Hikmat, H (2013) Strategi Pemberdayaan masyarakat. Bandung : Humaniora Utama.

Kaswan \& Ade Sadikin. (2015) Pengembangan Sumber Daya Manusia, Alfabeta, Bandung.

Stewart, A. M. (1998). Empowering People; Pemberdayaan Sumber Daya Manusia, Yogyakarta : Kanisius.

------------, (2000), Manajemen Program Pendidikan untuk Pendidikan Luar Sekolah dan Pengembangan Sumberdaya Manusia : Bandung Falah Production.

Suharto, E. (2005). Membangun Masyarakat Supriadi, D, (1995), Kreativitas, Kebudayaan, dan Perkembangan Iptek, Jakarta, Alfabeta

Sudjana. D (2000). Manajement Program Pendidikan Untuk Pendidikan Luar Sekolah dan Pengembangan Sumber Daya Manusia. Bandung: Falah Production.

Sugiono.(2010).Metode Penelitian Pendekatan Kuantitatif, Kualitatif dan R\&D. Bandung :Rosdakarya 